$\begin{array}{rr}\text { FIT(P)PATOLOGI } & \text { Volume 11, Nomor 6, Desember 2015 } \\ \text { I N D ONESIA } & \text { Halaman 179-186 } \\ \text { ISSN: } 0215-7950 & \text { DOI: } 10.14692 / \text { jfi.11.6.179 }\end{array}$

\title{
Bakteri Endofit dari Tanaman Kehutanan sebagai Pemacu Pertumbuhan Tanaman Tomat dan Agens Pengendali Meloidogyne sp.
}

\author{
Endophytic Bacteria from Forestry Plants as Plant Growth Promoting \\ and Control Agent of Meloidogyne sp. on Tomato
}

\author{
Abdul Munif*, Arif Rafi Wibowo, Elis Nina Herliyana \\ Institut Pertanian Bogor, Bogor 16680
}

\begin{abstract}
ABSTRAK
Meloidogyne sp. adalah nematoda parasit tumbuhan yang penting dan menjadi salah satu kendala dalam budi daya tanaman tomat di Indonesia. Bakteri endofit dapat menjadi agens hayati yang potensial untuk mengendalikan Meloidogyne sp. Tanaman kehutanan kaya akan mikrob yang bermanfaat, termasuk berbagai jenis bakteri endofit yang berpotensi sebagai agens hayati maupun pemacu pertumbuhan tanaman. Penelitian ini dilakukan untuk mendapatkan bakteri endofit dari beberapa jenis tanaman hutan dan mengevaluasi potensinya sebagai pemacu pertumbuhan serta agens pengendali Meloidogyne sp pada tanaman tomat. Bakteri endofit diisolasi dari akar tanaman mahoni (Swietenia mahagoni), trambesi (Albizia saman), gaharu (Aquilaria malacensis), dan meranti (Shorea sp.). Isolasi bakteri endofit dilakukan dengan metode sterilisasi permukaan menggunakan alkohol 70\% dan $\mathrm{NaOCl} 3 \%$ pada medium trypsic soy agar. Bakteri endofit yang tumbuh selanjutnya dipisahkan dan dimurnikan berdasarkan bentuk dan warna koloninya. Sebanyak 33 isolat bakteri endofit berhasil diisolasi dari akar tanaman mahoni (11 isolat), tanaman trambesi (5 isolat), tanaman gaharu (7 isolat), dan tanaman meranti (10 isolat). Uji reaksi hipersensitifitas bakteri endofit pada daun tembakau menunjukkan 22 isolat tidak menyebabkan nekrosis, yaitu tidak berpotensi sebagai patogen tanaman. Sebanyak 10 isolat bakteri endofit selanjutnya dipilih untuk diketahui potensinya sebagai agens hayati terhadap Meloidogyne sp. dan sebagai agens pemacu pertumbuhan tanaman tomat. Pengujian dilakukan dengan metode perendaman benih. Hasil pengamatan menunjukkan 2 isolat endofit, yaitu MSJ1H dan AGS1F, mampu menekan jumlah puru akar yang disebabkan oleh Meloidogyne sp. dan meningkatkan pertumbuhan tanaman tomat hingga $60 \%$. Bakteri endofit dari beberapa tanaman kehutanan berpotensi sebagai agens biokontrol terhadap Meloidogyne sp.
\end{abstract}

Kata kunci: gaharu, mahoni, meranti, trambesi, puru akar

\section{ABSTRACT}

Meloidogyne sp. is one of the main constraints of tomato production in Indonesia. Endophytic bacteria may be considered as biocontrol agents for controlling Meloidogyne sp. The objective of this study was to isolate endophytic bacteria from forestry plants and to evaluate its potential for controling Meloidogyne sp. on tomato. Endophytic bacteria were isolated from roots of mahoni (Swietenia mahogany), trambesi (Albizia saman), gaharu (Aquilaria malacensis), and meranti (Shorea sp.). Isolation of bacterial endophytes from plant tissue was conducted using surface sterilization method with $70 \%$ alcohol, $3 \% \mathrm{NaOCl}$ and sterile water on medium trypsic soy agar. Endophytic bacteria was separated and purified based on shape and color of the colony. A total of 33 isolates of endophytic

*Alamat penulis korespondensi: Departemen Proteksi Tanaman, Fakultas Pertanian, Institut Pertanian Bogor Jalan Kamper Darmaga, Bogor 16680.

Tel: 0251-8629364, Faks: 0251-8629362, Surel: munif73@gmail.com 
bacteria were isolated from roots of mahoni (11 isolates), trambesi (5 isolates), gaharu ( 7 isolates), and meranti (10 isolates). The bacteria was tested for the hypersensitivity reaction on tobacco plants and the result showed that 22 isolates did not cause necrosis, indicated they are not pathogenic. Ten isolates of endophytic bacteria was selected for further experiment, i.e. to evaluate their potential as biocontrol agents for Meloidogyne sp. and as growth promotor for tomato plants. The experiment was conducted in the screenhouse using seed treatment. The result showed that two isolates of endophytic bacteria, i.e. MSJ1H and AGS1F were able to increase the growth of tomato plants up to $60 \%$ and reduce the number of root knot caused by Meloidogyne sp. Endophytic bacteria isolated from forestry plants have the potential as a biocontrol agents to plant parasitic nematode Meloidogyne sp.

Key words: gaharu, mahoni, meranti, root knot, trambesi

\section{PENDAHULUAN}

Meloidogyne spp. yang menimbulkan kerugian besar pada pertanaman di daerah tropik dan subtropik ialah $M$. incognita, M. javanica, M. arenaria dan M. hapla. Kehilangan hasil yang disebabkannya pada tanaman sayuran di Indonesia berkisar 20-80\% (Hadisoeganda 1991). Pengendalian nematoda parasit yang dilakukan oleh petani umumnya menggunakan nematisida sintetis. Oleh karea itu, teknologi pengendalian yang ramah lingkungan dan berbasis pada potensi sumber daya lokal sangat diperlukan. Salah satu pilihan yang dapat dikembangkan ialah pengendalian biologi menggunakan bakteri endofit.

Bakteri endofit yang diisolasi dari beberapa tanaman dilaporkan dapat mengendalikan nematoda puru akar Meloidogyne spp dan Pratylenchus brachyurus hingga $74 \%$ pada tanaman tomat dan nilam (Harni et al. 2007; Munif et al. 2013). Formulasi bakteri endofit asal akar kedelai juga dilaporkan dapat menekan serangan penyakit pustul bakteri yang disebabkan oleh Xanthomonas axonopodis pv. glycines pada kedelai (Habazar et al. 2015).

Tanaman kehutanan terutama jenisjenis yang asli diduga sangat kaya akan mikrob yang bermanfaat, termasuk berbagai jenis mikrob endofit yang sangat beragam (Izumi 2011). Nongkhlaw dan Joshi (2014) melaporkan sekitar 70 bakteri endofit hasil isolasi dari beberapa jenis tanaman obat yang berasal dari hutan subtropis di Meghalaya, India mampu meningkatkan pertumbuhan tanaman dan menekan aktivitas patogen pada tanaman yang diuji.
Di Indonesia penelitian terkait mikrob endofit dari tanaman hutan sudah dimulai namun masih didominasi penelitian cendawan endofit. Hal ini semakin mendorong perlunya dilakukan penelitian bakteri endofit dari tanaman hutan. Penelitian ini bertujuan mendapatkan bakteri endofit dari tanaman hutan dan mengevaluasi potensinya sebagai pemacu pertumbuhan dan agens pengendali Meloidogyne sp. pada tanaman tomat.

\section{BAHAN DAN METODE}

\section{Isolasi Bakteri Endofit}

Isolat bakteri endofit diisolasi dari akar bibit tanaman mahoni, trambesi, gaharu, dan meranti yang tumbu sehat (tidak menunjukkan gejala sakit). Pemilihan fase bibit sebagai sumber isolat bakteri endofit karena pertimbangan kemudahan pada perakarannya yang masih muda atau lunak sehingga mudah dalam penggerusan. Bibit tanaman yang digunakan berumur 4-5 bulan. Isolasi bakteri endofit dilakukan mengikuti metode sterilisasi permukaan. Bibit tanaman kehutanan dicabut dan akarnya dicuci bersih dengan air mengalir dan diletakkan di atas kertas. Selanjutnya akar tanaman yang sudah bersih diambil sebanyak $2 \mathrm{~g}$ dan dipotong berukuran 1-2 cm. Akar direndam dalam alkohol $70 \%$ selama 1 menit, $\mathrm{NaOCl} 3 \%$ selama 1 menit selanjutnya dibilas dengan akuades steril sebanyak 3 kali. Akar tersebut kemudian digerus dengan mortar steril sampai halus dan ditambah $10 \mathrm{~mL}$ akuades steril. Suspensi diencerkan dan sebanyak $0.1 \mathrm{~mL}$ ditumbuhkan dengan cara disebar pada 
medium TSA $10 \%$ dan diinkubasi selama 48 jam. Koloni bakteri yang tumbuh dihitung dan dimurnikan pada medium trypsic soy agar (TSA) 100\%. Selanjutnya bakteri endofit ditumbuhkan dalam medium trypsic soy broth (TSB) yang dicampur dengan gliserol 20\% dan disimpan pada suhu $-4{ }^{\circ} \mathrm{C}$ untuk koloni biakan dan koloni kerja.

\section{Uji Hipersensitifitas}

Uji hipersensitifitas (HR) dilakukan untuk menentukan potensi patogenesitas bakteri endofit. Tanaman yang digunakan dalam uji HR ialah tembakau varietas Xanthi sehat berumur 2-3 bulan yang diperoleh dari Balai Besar Penelitian dan Pengembangan Bioteknologi dan Genetik Pertanian, Bogor.

Isolat bakteri endofit dibiakkan pada medium TSA $100 \%$ dan diinkubasi selama 48 jam. Koloni bakteri endofit disuspensikan dalam $20 \mathrm{~mL}$ akuades steril dan diinfiltrasikan menggunakan jarum suntik pada bagian bawah daun tembakau dan diinkubasi selama 24 jam. Apabila daun tembakau tidak menujukkan gejala nekrosis setelah 24 jam maka bakteri endofit tidak berpotensi sebagai patogen dan digunakan untuk penelitian selanjutnya.

\section{Pengaruh Bakteri Endofit terhadap Pertumbuhan Tanaman}

Pengujian dilakukan di rumah kaca menggunakan tanaman tomat varietas Permata yang bersifat rentan terhadap Meloidogyne sp. (Rosya 2015). Sebanyak $5 \mathrm{~g}$ benih tomat varietas Permata direndam dalam akuades steril, benih yang terendam diambil dan dikeringanginkan di atas kertas. Selanjutnya benih tomat tersebut direndam ke dalam suspensi bakteri endofit dengan kepadatan populasi $10^{8}-10^{10} \mathrm{cfu} \mathrm{mL}^{-1}$ yang telah ditambah dengan 2\% metil selulosa selama 30 menit dan 120 menit (Munif et al. 2012). Benih selanjutnya ditanam dalam pot plastik volume $3 \mathrm{~kg}$ yang berisi medium tanah dan bahan organik (2:1). Setelah 3 minggu inokulasi, tanaman dibongkar dan diamati pertumbuhnya, yaitu tinggi, bobot basah, dan bobot kering tajuk.

\section{Uji Bakteri Endofit terhadap Meloidogyne sp.}

Benih tomat varietas Permata direndam selama 30 menit dan 120 menit ke dalam suspensi bakteri endofit dengan kepadatan populasi $10^{8}-10^{10} \mathrm{cfu} \mathrm{mL}^{-1}$ yang telah ditambah dengan metil selulosa 2\%. Benih ditanam dalam pot yang sudah diisi dengan medium tanah dan bahan organik (2:1) (Khaeruni dan Rahman 2012). Selanjutnya setelah berumur 1 minggu, tanaman diinokulasi dengan larva nematoda Meloidogyne spp., masing-masing 300 ekor per pot. Larva Meloidogyne spp. diekstraksi dari akar tanaman tomat yang terserang Meloidogyne dari lapangan menggunakan metode corong Boermann dan pengabutan. Masing-masing perlakuan diulang sebanyak 5 kali dan disusun dalam rancangan acak lengkap. Selanjutnya tanaman dibongkar dan diamati jumlah puru akarnya 1 bulan setelah inokulasi.

Mortalitas nematoda ditentukan dengan uji antibiosis. Bakteri endofit ditumbuhkan pada medium TSB selama 48 jam pada suhu ruang. Koloni tunggal dipindahkan ke dalam $100 \mathrm{~mL}$ medium TSB dan digoyang selama 2 hari dengan kecepatan $150 \mathrm{rpm}$ pada suhu ruang. Suspensi bakteri endofit diuji aktivitas antibiosisnya terhadap larva instar 2 nematoda Meloidogyne sp. (Oostendorp dan Sikora 1990). Suspensi bakteri endofit sebanyak $5 \mathrm{~mL}$ dengan kepadatan $10^{9} \mathrm{cfu} \mathrm{mL}^{-1}$ dimasukkan ke dalam cawan sirakus, selanjutnya sebanyak 20 ekor larva nematoda dimasukkan ke dalam gelas tersebut.

Pengamatan mortalitas larva nematoda dilakukan 24 jam setelah perlakuan menggunakan mikroskop binokuler. Suspensi larva nematoda dimasukkan ke dalam air steril dan diberi aerasi selama 5 menit untuk memastikan larva nematoda benar-benar mati atau hanya istirahat. Apabila di dalam air tersebut nematoda tidak bergerak maka nematoda tersebut mati.

\section{HASIL}

\section{Bakteri Endofit dan Uji Hipersensitif}

Sebanyak 33 isolat bakteri endofit berhasil diisolasi dari perakaran bibit tanaman mahoni, 
trambesi, gaharu, dan meranti; masingmasing 11, 5, 7, dan 10 isolat. Isolat bakteri endofit tersebut diuji hipersensitif pada daun tembakau dan 11 isolat menunjukkan gejala nekrosis (reaksi positif), sedangkan 22 isolat tidak menunjukkan gejala nekrosis (reaksi negatif) (Tabel 1).

\section{Pengujian di Rumah Kaca}

Isolat bakteri endofit yang tidak menimbulkan gejala nekrosis pada daun tembakau digunakan pada uji lanjut. Dari 22 isolat bakteri endofit ini ternyata hanya 10 isolat yang dapat meningkatkan pertumbuhan tanaman tomat di rumah kaca. Isolat bakteri endofit yang terpilih ini selanjutnya diujikan pada benih tomat. Lebih dari separuh isolat bakteri endofit dapat meningkatkan tinggi tanaman tomat pada perlakuan perendaman benih selama 30 menit dibandingkan dengan kontrol dan hanya 1 isolat yang berpegaruh terhadap bobot tanaman (Tabel 2). Perlakuan perendaman 120 menit menunjukkan hanya 3 isolat, yaitu MSJ1H, AGS1H, dan AMS1A yang dapat meningkatkan tinggi tanaman dibandingkan dengan kontrol dan perlakuan isolat lainnya.

Hasil pengujian 10 isolat bakteri endofit terhadap Meloidogyne sp. menunjukkan bahwa perlakuan perendaman benih selama 30 menit terdapat satu isolat, yaitu MSJIH yang dapat menekan jumlah puru akar dibandingkan dengan kontrol; sedangkan dengan perlakuan perendaman selama 120 menit menunjukkan 3 isolat bakteri endofit, yaitu MSJ1H, TSS1D dan AGS1F mampu menekan jumlah puru akar pada tanaman tomat (Tabel 3).

\section{Pengujian Suspensi Bakteri Endofit secara in Vitro}

Pengujian secara in vitro suspensi bakteri endofit terhadap mortalitas larva Meloidogyne sp., menunjukkan bahwa perlakuan dengan 3 isolat bakteri endofit TSS1D, AGS1F, dan MSJ1H dapat meningkatkan jumlah larva Meloidogyne sp. yang inaktif dibandingkan dengan kontrol (tanpa suspensi bakteri endofit). Perlakuan dengan suspensi isolat bakteri endofit menunjukkan hasil yang tidak berbeda nyata dengan kontrol pada pengamatan 2 jam maupun 6 jam setelah perlakuan, kecuali perlakuan isolat TSS1D (Tabel 4).

\section{PEMBAHASAN}

Tanaman dalam kehidupannya selalu berasosiasi dengan mikrob termasuk mikrob endofit. Jumlah bakteri endofit yang berhasil

Tabel 1 Bakteri endofit yang diisolasi dari tanaman kehutanan dan hasil uji reaksi hipersensitifitas pada tanaman tembakau

\begin{tabular}{|c|c|c|c|c|c|}
\hline Isolat & Tanaman & Uji Hipersensitif & Isolat & Tanaman & Uji Hipersensitif \\
\hline MSJ1A & Mahoni & Negatif & AGS1B & Gaharu & Positif \\
\hline MSJ1B & Mahoni & Positif & AGS1C & Gaharu & Positif \\
\hline MSJ1C & Mahoni & Positif & AGS1D & Gaharu & Negatif \\
\hline MSJ1D & Mahoni & Negatif & AGS1E & Gaharu & Positif \\
\hline MSJ1E & Mahoni & Positif & AGS1F & Gaharu & Negatif \\
\hline MSJ1G & Mahoni & Negatif & AGS1H & Gaharu & Negatif \\
\hline MSJ1H & Mahoni & Negatif & AMS1A & Meranti & Negatif \\
\hline MSJ1I & Mahoni & Negatif & AMSID & Meranti & Negatif \\
\hline MSJ2A & Mahoni & Positif & AMS1E & Meranti & Negatif \\
\hline MSJ2D & Mahoni & Positif & AMS1F & Meranti & Negatif \\
\hline MSJ2G & Mahoni & Negatif & AMS1H & Meranti & Negatif \\
\hline TSS1B & Trambesi & Positif & AMS2A & Meranti & Negatif \\
\hline TSS1C & Trambesi & Positif & AMS2B & Meranti & Negatif \\
\hline TSS1D & Trambesi & Negatif & AMS2D & Meranti & Negatif \\
\hline TSS1E & Trambesi & Positif & AMS2E & Meranti & Negatif \\
\hline $\mathrm{TSS} 2 \mathrm{~A}$ & Trambesi & Negatif & AMS2H & Meranti & Negatif \\
\hline AGS1A & Gaharu & Negatif & & & \\
\hline
\end{tabular}


Tabel 2 Pengaruh perlakuan perendaman benih dengan bakteri endofit asal tanaman kehutanan terhadap tinggi, bobot basah dan bobot kering tanaman tomat pada percobaan di rumah kaca

\begin{tabular}{|c|c|c|c|c|c|c|}
\hline \multirow[b]{2}{*}{ Isolat* } & \multicolumn{3}{|c|}{ Perendaman 30 menit } & \multicolumn{3}{|c|}{ Perendaman 120 menit } \\
\hline & $\begin{array}{c}\text { Tinggi } \\
\text { tanaman } \\
(\mathrm{cm})\end{array}$ & $\begin{array}{c}\text { Bobot } \\
\text { basah } \\
(\mathrm{g})\end{array}$ & $\begin{array}{l}\text { Bobot } \\
\text { kering } \\
\text { (g) }\end{array}$ & $\begin{array}{l}\text { Tinggi } \\
\text { tanaman } \\
(\mathrm{cm})\end{array}$ & $\begin{array}{c}\text { Bobot } \\
\text { basah } \\
(\mathrm{g})\end{array}$ & $\begin{array}{c}\text { Bobot } \\
\text { kering } \\
(\mathrm{g})\end{array}$ \\
\hline MSJ1H & $22.34 \mathrm{ab}$ & $1.66 \mathrm{bc}$ & $0.13 \mathrm{~b}$ & $24.38 \mathrm{a}$ & $1.87 \mathrm{abc}$ & $0.12 \mathrm{abc}$ \\
\hline AGS1F & $15.00 \mathrm{~b}$ & $1.09 \mathrm{c}$ & $0.11 \mathrm{ab}$ & $19.34 \mathrm{ab}$ & $1.63 \mathrm{bc}$ & $0.11 \mathrm{abcd}$ \\
\hline TSS1D & $24.06 \mathrm{a}$ & $1.75 b c$ & $0.13 \mathrm{a}$ & $22.92 \mathrm{a}$ & $2.07 \mathrm{ab}$ & $0.15 \mathrm{a}$ \\
\hline AGS1H & $23.60 \mathrm{a}$ & $1.81 \mathrm{abc}$ & $0.10 \mathrm{ab}$ & $25.60 \mathrm{a}$ & $2.05 \mathrm{ab}$ & $0.12 \mathrm{abc}$ \\
\hline MSJ1A & $23.02 \mathrm{a}$ & $1.74 \mathrm{bc}$ & $0.10 \mathrm{ab}$ & $22.94 \mathrm{a}$ & $1.73 \mathrm{abc}$ & $0.10 \mathrm{abcd}$ \\
\hline AGS1D & $23.26 \mathrm{a}$ & $1.99 \mathrm{ab}$ & $0.11 \mathrm{ab}$ & $22.30 \mathrm{a}$ & $1.59 \mathrm{bc}$ & $0.09 \mathrm{abcd}$ \\
\hline AMS1A & $15.08 \mathrm{~b}$ & $1.07 \mathrm{c}$ & $0.07 \mathrm{~b}$ & $25.00 \mathrm{a}$ & $1.62 \mathrm{bc}$ & $0.09 \mathrm{abcd}$ \\
\hline AGS1A & $20.60 \mathrm{ab}$ & $1.85 \mathrm{abc}$ & $0.10 \mathrm{ab}$ & $20.10 \mathrm{ab}$ & $1.28 \mathrm{bc}$ & $0.07 \mathrm{~cd}$ \\
\hline AMS1D & $24.04 \mathrm{a}$ & $2.61 \mathrm{a}$ & $0.14 \mathrm{a}$ & $18.14 \mathrm{ab}$ & $1.44 \mathrm{bc}$ & $0.07 \mathrm{bcd}$ \\
\hline TSS2A & $25.38 \mathrm{a}$ & $1.84 \mathrm{abc}$ & $0.09 \mathrm{ab}$ & $11.74 \mathrm{~b}$ & $0.85 \mathrm{c}$ & $0.05 \mathrm{~d}$ \\
\hline Kontrol & $14.94 \mathrm{~b}$ & $1.76 \mathrm{bc}$ & $0.08 \mathrm{ab}$ & $22.56 \mathrm{a}$ & $2.68 \mathrm{a}$ & $0.14 \mathrm{ab}$ \\
\hline
\end{tabular}

Angka-angka pada kolom yang sama yang diikuti oleh huruf yang sama tidak berbeda nyata pada taraf uji $\alpha .5 \%$ berdasarkan uji selang berganda Duncan.

* Keterangan tentang sumber isolat ada pada Tabel 1

Tabel 3 Pengaruh perlakuan perendaman benih dengan bakteri endofit terhadap jumlah puru akar pada tanaman tomat pada percobaan di rumah kaca

\begin{tabular}{lcccc}
\hline \multirow{2}{*}{ Isolat* } & \multicolumn{2}{c}{ Perendaman 30 menit } & \multicolumn{2}{c}{ Perendaman 120 menit } \\
\cline { 2 - 5 } & Jumlah puru & $\begin{array}{c}\text { Persentase penekanan } \\
(\%)\end{array}$ & Jumlah puru & $\begin{array}{c}\text { Persentase penekanan } \\
(\%)\end{array}$ \\
\hline MSJ1H & $6.80 \mathrm{a}$ & 21 & $4.40 \mathrm{~d}$ & 67 \\
AGS1F & $8.60 \mathrm{a}$ & 0 & $6.20 \mathrm{~cd}$ & 54 \\
TSS1D & $11.20 \mathrm{a}$ & -30 & $10.00 \mathrm{bcd}$ & 26 \\
AGS1H & $15.20 \mathrm{a}$ & -75 & $23.80 \mathrm{abc}$ & -75 \\
MSJ1A & $22.40 \mathrm{a}$ & -155 & $13.80 \mathrm{abcd}$ & -1 \\
AGS1D & $21.20 \mathrm{a}$ & -124 & $23.00 \mathrm{abcd}$ & -69 \\
AMS1A & $15.60 \mathrm{a}$ & -81 & $22.20 \mathrm{abcd}$ & -63 \\
AGS1A & $11.80 \mathrm{a}$ & -37 & $14.60 \mathrm{abcd}$ & -75 \\
AMS1D & $14.80 \mathrm{a}$ & -72 & $28.00 \mathrm{ab}$ & -105 \\
TSS2A & $18.60 \mathrm{a}$ & -116 & $32.40 \mathrm{a}$ & -135 \\
Kontrol & $8.60 \mathrm{a}$ & 0 & $13.60 \mathrm{abcd}$ & 0 \\
\hline Antal
\end{tabular}

Angka-angka pada kolom yang sama yang diikuti oleh huruf yang sama tidak berbeda nyata pada taraf uji $\alpha 5 \%$ berdasarkan uji selang berganda Duncan.

*Keterangan tentang sumber isolat ada pada Tabel 1

Tabel 4 Pengaruh suspensi bakteri endofit terhadap mortalitas larva Meloidogyne spp secara in vitro

\begin{tabular}{llc}
\hline Isolat* & 2 jam & 6 jam \\
\hline TSS1D & $30.33 \mathrm{a}$ & $38.67 \mathrm{a}$ \\
AGS1F & $26.67 \mathrm{ab}$ & $42.00 \mathrm{a}$ \\
MSJ1H & $26.33 \mathrm{ab}$ & $36.67 \mathrm{a}$ \\
Kontrol & $12.33 \mathrm{~b}$ & $31.00 \mathrm{a}$ \\
\hline
\end{tabular}

Angka-angka pada kolom yang sama yang diikuti oleh huruf yang sama tidak berbeda nyata pada taraf uji $\alpha 5 \%$ berdasarkan uji selang berganda Duncan.

*Keterangan tentang sumber isolat ada pada Tabel 1 
diisolasi dari tiap tanaman yang digunakan dalam penelitian ini bervariasi antar satu tanaman dengan tanaman lainnya. Jumlah bakteri ditentukan oleh banyak faktor seperti jenis tanaman, umur tanaman, tempat tumbuh tanaman dan teknik isolasi, seperti proses sterilisasi permukaan, waktu isolasi dan medium isolasi yang digunakan (Hallmann et al. 1997). Sebanyak 33 isolat bakteri endofit berhasil diisolasi dari 4 jenis tanaman tergolong sedikit. Hal ini diduga karena bakteri endofit yang diisolasi pada penelitian ini hanya dari bagian akar tanaman, padahal bakteri endofit dapat hidup dan berasosiasi hampir pada semua bagian tanaman termasuk batang dan daun. Khianngam et al (2013) mendapatkan 31 isolat bakteri endofit yang diisolasi dari akar dan kulit tanaman yang diambil di hutan mangrove di Pranburi, Prachuap Khiri Khan, Thailand. Sementara Castro et al (2014) telah mengisolasi 30 jenis bakteri endofit dari 2 spesies tanaman yang berasal dari hutan bakau tropis di Brazil, yaitu Rhizophora mangle dan Avicennia nitida. Genus bakteri endofit yang behasil diisolasi ialah Bacillus sp., Pantoea, Curtobacterium dan Enterobacter. namun belum diketahui pengaruhnya terhadap pertumbuhan tanaman maupun sebagai agens hayati.

Nongkhlaw dan Joshi (2014), telah mengisolasi bakteri endofit dari beberapa jenis tanaman obat yang berasal dari hutan subtropis Meghalaya, India dan berhasil diperoleh 70 isolat bakteri endofit dari kelompok Bacillus sp., Serratia sp., Pseudomonas sp., Pantoea sp., dan Lysinibacillus sp. Beberapa endofit dilaporkan mampu meningkatkan pertumbuhan tanaman dan menekan aktivitas patogen tanaman yang diuji. Hasil penelitian menunjukkan perbedaan yang signifikan dalam populasi bakteri tidak hanya antara habitat mikro epifit dan endofit, tetapi juga di antara tanaman inang. Hidayati et al. (2014) melaporkan beberapa bakteri endofit yang diisolasi dari tanaman karet dapat meningkatkan pertumbuhan bibit karet yang diduga karena kemampuannya dalam menghasilkan hormon pertumbuhan seperti auksin, gibberellin, sitokinin dan asam absisat.
Perlakuan bakteri endofit dengan perendaman benih menunjukkan bahwa perendaman selama 30 menit lebih baik dibandingkan dengan perendaman selama 120 menit terhadap tinggi tanaman, bobot basah dan bobot kering tanaman. Hasil penelitian ini sesuai dengan penelitian yang pernah dilakukan Munif et al. (2012), bahwa perlakuan benih tomat dengan bakteri endofit dapat meningkatkan bobot basah akar dan panjang akar tanaman tomat. Perendaman akar bibit lada dengan beberapa isolat bakteri endofit yang diisolasi dari tanaman lada juga dapat meningkatkan bobot akar dan bobot tajuk tanaman lada (Munif dan Harni 2011; Harni dan Ibrahim 2011).

Peningkatkan pertumbuhan tanaman oleh perlakuan dengan bakteri endofit diduga karena bakteri endofit dapat meningkatkan fiksasi nitrogen, aktivitas fotosintesis, dan produksi indole acetic acid (IAA) (Duangpaeng et al. 2012; Lopez et al 2012). Nongkhlaw dan Joshi (2014) melaporkan bahwa bakteri endofit mampu meningkatkan pertumbuhan tanaman karena menghasilkan komponen penting bagi pertumbuhan tanaman seperti mineral fosfat, aktivitas asam fosfatase, adanya deaminase asam 1-aminocyclopropane-1-karboksilat (ACC). Di samping itu interaksi bakteri endofit dengan tanaman dapat menghasilkan lipopolisakarida yang berperan sebagai elisitor dalam induksi ketahanan yang secara spesifik mengikat reseptor pada permukaan sel tanaman (Reitz et al. 2000).

Hasil uji in vitro terhadap larva Meloidogyne spp menunjukkan suspensi isolat AGS1F memberikan pengaruh tertinggi (42\%) terhadap mortalitas larva Meloidogyne sp. tetapi tidak berbeda nyata dengan perlakuan isolat yang lain. Larva Meloidogyne sp. yang mati atau inaktif diduga karena adanya pengaruh senyawa metabolit yang dihasilkan oleh bakteri endofit. Senyawa metabolit yang dihasilkan oleh bakteri endofit di antaranya, pelarut fosfat dan enzim penghidrolisa seperti kitinase, protease, selulase, lipase, dan pektinase (Berg dan Hallmann 2006).

Hasil penelitian ini menunjukkan bahwa bakteri endofit yang berasal dari tanaman 
kehutanan berpotensi sebagai pemacu pertumbuhan tanaman dan agens pengendali nematoda parasit. Penelitian ini memang tidak dimaksudkan untuk melihat keragaman dan dinamika populasi bakteri endofit dari tanaman kehutanan. Penelitian ini hanya menguji beberapa bakteri endofit yang berhasil diisolasi dari bagian akar tanaman hutan (khususnya bibit tanaman hutan) yang berpotensi sebagai agens hayati dan pemacu pertumbuhan. Penelitian untuk mengetahui keragaman dan dinamika bakteri endofit yang diisolasi langsung dari tanamantanaman hutan di lapangan dan dari berbagai jenis hutan perlu dilakukan. Potensi bakteri endofit asli dari tanaman-tanaman hutan yang sangat banyak jenisnya akan menjadi sumber kekayaan hutan (selain kayu) untuk kepentingan pertanian, kedokteran dan industri juga akan sangat penting untuk mendukung kekayaan biodiversitas hutan. Informasi dalam penelitian ini merupakan informasi awal tentang bakteri endofit tanaman hutan yang potensial sebagai agens hayati dan pemacu pertumbuhan tanaman yang akan mendorong penelitian-penelitian selanjutnya.

\section{UCAPAN TERIMA KASIH}

Penulis mengucapkan terima kasih kepada Pimpinan IPB melalui skema Penelitian Fundamental untuk Perguruan Tinggi bagian BOPTN atas dukungan dana dalam pelaksanaan penelitian ini.

\section{DAFTAR PUSTAKA}

Berg G, Hallmann J. 2006. Control of plant pathogenic fungi with bacterial endophytes. Di dalam: Schulz BJE, Boyle CJC, Sieber TN, editor. Microbial Root Endophytes. Verlag Berlin Heidelberg (DE): Springer. hlm 53-66.

Castro RA, Quecine MC, Lacava PT, Batista BD, Luvizotto DM, Marcon J, Ferreira A, Melo IS, Azevedo JL. 2014. Isolation and enzyme bioprospection of endophytic bacteria associated with plants of Brazilian mangrove ecosystem. Springer Plus. 3:382. DOI: $\quad$ http://dx.doi.org/10.1186/21931801-3-382.

Duangpaeng A, Phetcharat P, Chanthapho S, Boonkantong N, Okuda N. 2012. The study and development of endophytic bacteria for enhancing organic rice growth. Procedia Engineering. 32:172176. DOI: http://dx.doi.org/10.1016/j. proeng.2012.01.1253.

Habazar T, Resti Z, Yanti Y, Sutoyo, Imelda. 2015. Formulasi bakteri endofit akar kedelai untuk mengendalikan pustul bakteri. J Fitopatol Indones. 11(2):51-58. DOI: http://dx.doi.org/10.14692/jfi.11.2.51. Hadisoeganda AW. 1991. Pencaran, identifikasi dan prevalensi nematoda bengkak akar di sentra daerah penanaman sayuran dataran tinggi di Indonesia. Buletin Penelitian Hortikultura. 20(3): 62-71.

Hallmann J, Hallmann AQ, Mahaffee WF, Kloepper JW. 1997. Bacterial endophytes in agricultural crops. Can J Microbiol. 43(10):895-914. DOI: http://dx.doi. org/10.1139/m97-131.

Harni R, Ibrahim MSD. 2011. Potensi bakteri endofit menginduksi ketahanan tanaman lada terhadap infeksi Meloidogyne incognita. J Littri.17(3):118-123.

Harni R, Munif A, Supramana, Mustika I. 2007. Pemanfaatan bakteri endofit untuk mengendalikan nematoda peluka akar (Pratylenchus brachyurus) pada tanaman nilam. J HAYATI J Biosci. 14(1):7-12.

Hidayati U, Chaniago IA, Munif A, Siswanto, Santosa DA. 2014. Potency of plant growth promoting endophytic bacteria from rubber plants (Hevea brasiliensis Mill. Arg.) J Agronomy. 13(3):147-152. DOI: http:// dx.doi.org/10.3923/ja.2014.147.152.

Izumi H. 2011. Diversity of endophytic bacteria in forest trees. Di dalam: Pirttila AM, Frank AC, editor. Endophytes of Forest Trees.Verlag Berlin Heidelberg (DE): Springer. hlm 95-105. DOI: http:// dx.doi.org/10.1007/978-94-007-1599-8_6.

Khaeruni A, Rahman A. 2012. Penggunaan Bakteri kitinolitik sebagai agens biokontrol 
penyakit busuk batang oleh Rhizoctonia solani pada tanaman kedelai. J Fitopatol Indones 8(2):37-43.

Khianngam S, Techakriengkrai T, Raksasiri BV, Kanjanamaneesathian M, Tanasupawat S. 2013. Isolation and screening of endophytic bacteria for hydrolytic enzymes from plant in mangrove forest at Pranburi, Prachuap Khiri Khan, Thailand. Di dalam: Schneider C, Leifert C, Feldmann F, editor. Endophytes for Plant Protection: The State of The Art. Berlin (DE): Deutsche Phytomedizinische Gesellschaft, Braunschweig. hlm.279-284.

Lopez BR, Tinoco-Ojanguren C, Bacilio M, Mendoza A, Bashan Y. 2012. Endophytic bacteria of the rock-dwelling cactus Mammillaria fraileana affect plant growth and mobilization of elements from rocks. Environmental and Experimental Botany. 81(2012):26-36. DOI: http://dx.doi. org/10.1016/j.envexpbot.2012.02.014.

Munif A, Harni R. 2011. Keefektifan bakteri endofit untuk mengendalikan nematoda parasit Meloidogyne incognita pada tanaman lada. Buletin Ristri. 2(3):377-382.

Munif A, Hallmann J, Sikora RA. 2013. The Influence of endophytic bacteria on Meloidogyne incognita infection and tomato plant growth. J ISSAAS. 19 (2): $68-74$.
Munif A, Wiyono S, Suwarno. 2012. Isolasi bakteri endofit asal padi gogo dan potensinya sebagai agens biokontrol dan pemacu pertumbuhan. J Fitopatol Indones. 8(3):57-64.

Nongkhlaw FM, Joshi SR. 2014. Epiphytic and endophytic bacteria that promote growth of ethnomedicinal plants in the subtropical forests of Meghalaya, India. Rev Biol Trop 62(4):1295-308. DOI: http://dx.doi. org/10.15517/rbt.v62i4.12138.

Oostendorp M, Sikora RA. 1990. In-vitro interrelationship between rhizosphere bacteria and Heterodera schachtii. Rev. Nematol. 13:269-274.

Reitz M, Rudolph K, Schroeder I, HoffmannHergarten S, Hallmann J, Sikora RA. 2000. Lipopolysccharides of Rhizobium etli G12 act in potato root as an inducing agent of systemic resistance to infection by the cyst nematode Globodera pallida. Applied and Environ. Microbiol 66(8):35153518. DOI: http://dx.doi.org/10.1128/ AEM.66.8.3515-3518.2000.

Rosya A. 2015. Keefektifan limbah Brassica sebagai biofumigan dalam pengendalian nematoda puru akar (Meloidogyne sp.) pada tanaman tomat. [tesis]. Bogor (ID): Institut Pertanian Bogor. 